\title{
David Sanders (1944-2019) and his struggle for health
}

Anthony Costello, Professor of Global Health and Sustainable Development, University College, London

Although I had known David Sanders since 1986 through various meetings, and been strongly influenced by him, it was not until July 2018 I could make the trip to South Africa to spend a few days with him, his wife Sue Fawcus and his sons, Oscar and Ben. For all his gruff and fearless politics, and his forensic interrogation of global institutions, he was a great family person. He spoke openly of his pride in the achievements of Sue, his sons and daughter Lisa. He told hilarious stories about fly-fishing all over the world, most notably with his pal George Melly, the jazz singer, art critic and surrealist. He also spoke with great pride of the People's Health Movement, which he helped to found, their recent conference and the network of advocacy it had created. And he told me all about his staff and students, the people he'd brought on and mentored, all of whom loved him for his warmth, enthusiasm and constructive criticism.

David Sanders trained in Rhodesia where he was radicalised about colonialism and race. At his elite school he was a forthright Jewish boy who suffered considerable abuse for his views. By 1971, he had completed his medical training in Harare and, after being arrested, migrated to the UK.

"Working at St Thomas's Hospital I moved on from colonialism and race to discover the British class system” he told me. So he joined the medical committee against private practice, the politics of health group led by social scientist Lesley Doyal, and took courses at the London School of Hygiene and Tropical Medicine. He also read the works of Vicente Navarro, the sociologist and political scientist from Johns Hopkins University, which inspired him to write his first book, The Struggle for Health: Medicine and the Politics of Under-development, published in 1985.

With Zimbabwean independence in 1980, he decided to return home. "There is a window of opportunity after any political revolution when you can achieve many great and enduring changes”, he said. Over the next 12 years he ran the Oxfam rural health programme, joined the Harare Medical school as a Lecturer in Paediatrics, and then defected to the Department of Community Medicine where he could work more easily for the public health of women and children. His mission was to demonstrate that it was possible to implement the Alma Ata Declaration and comprehensive primary health care (PHC). Over the next decade Zimbabwe's infant mortality rate halved and their literacy rates more than doubled. But well before he left for South Africa, in 1992, David had become disillusioned by the repression inside both independence parties, Zanu PF and 
Zapu, and his shock at the Matabeleland massacres orchestrated by the current Zimbabwe President Emmerson Mnangagwa. He was also horrified by the apparent collusion of Oxfam and the British Foreign Office in covering up the massacres. For David the liberation movement had gone bad.

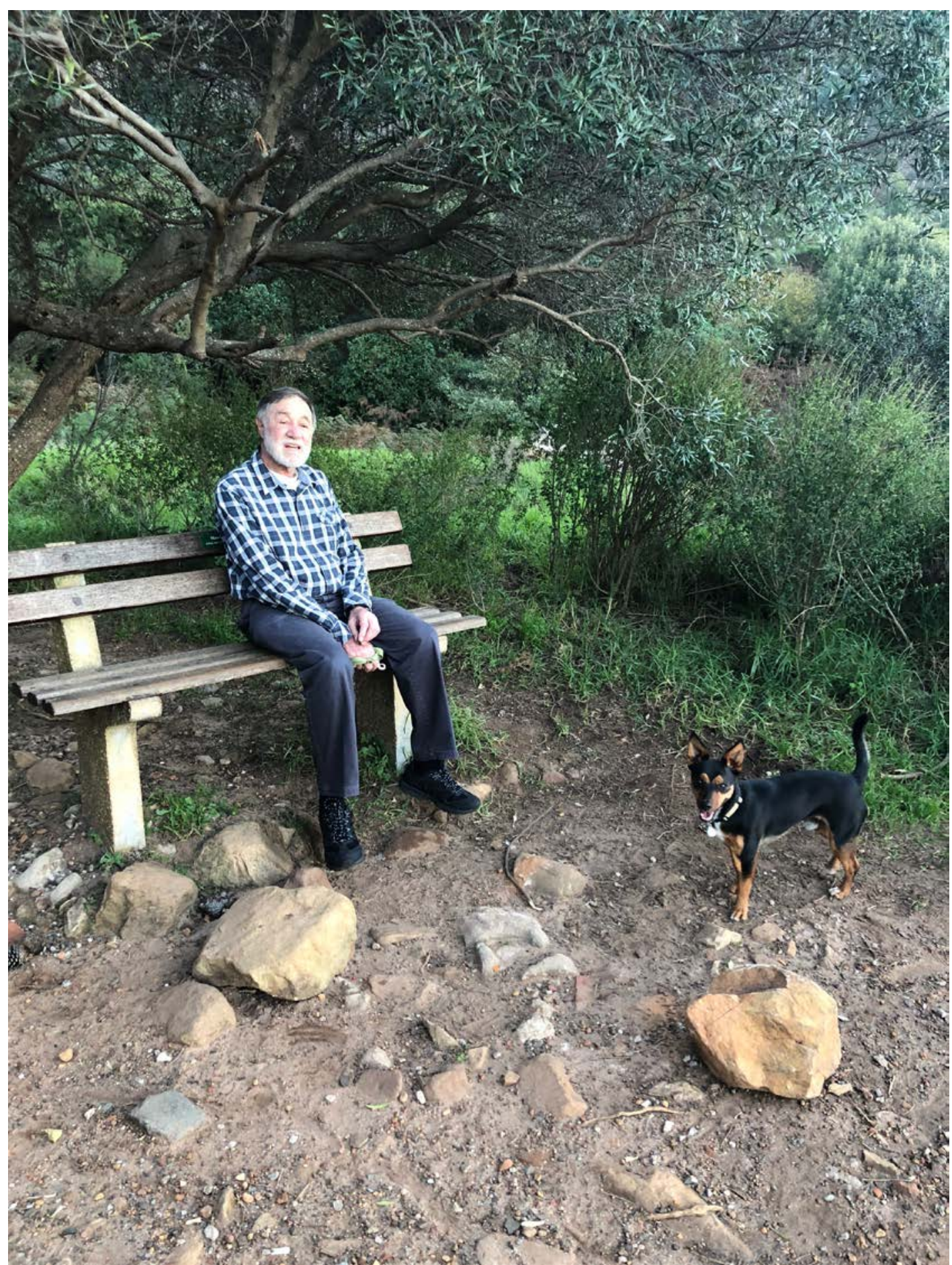

David below Table Mountain, Cape Town July 2018 
But in South Africa, a second liberation and window of opportunity had opened. In 1992 David joined the black University of Western Cape in Cape Town, and became the Head of the School of Public Health from its inception in 1993 until he handed over in 2009. With the mass mobilisation of the country after Nelson Mandela was elected President, David set to work. He was passionate about training a new generation of young South Africans, many of whom had been educationally deprived by the brutality and austerity of apartheid.

Meanwhile, he wrote more books which challenged the new world order of neoliberalism and structural adjustment. 'Questioning the Solution' argued that the attention given to the magic bullet of oral rehydration solution was undermined by the neglect of governments and donors for sanitation, water supply and food security. His edited book, 'Fatal Indifference: The G8, Africa and Global Health' challenged the hypocrisy of countries that boasted about aid yet imposed the severest programmes of public service cuts on low income countries through harmful IMF and World Bank structural adjustment policies.

But David didn’t just shout from outside the tent. From 2002 - 2006 he participated actively and constructively in the United Nations Standing Committee on Nutrition, and became a member of the Knowledge Network of the WHO Commission on Social Determinants of Health which published an influential report in 2008, even more relevant today.

'We have a global economic system whose ideology is neoliberalism....let the market rule,' he told me. 'Neoliberalism has overtaken capitalism, socialism and social democracy. It totally dominates our work today in the Peoples Health Movement... you find much emphasis on drugs and vaccines and appropriate technology but very little on the other pillars of PHC. Community participation, intersectoral collaboration, promotive and preventive strategies are all neglected. Above all we have seen no attempt to introduce a New International Economic Order (NIEO).”

He was also pessimistic about the effects of the financial crisis and the response of politicians who imposed austerity on the poorest and moved towards populist nationalism. 'I don't believe that social democracy can be maintained when there are capitalist crises,' he said. 'Capitalism will always overproduce, driven by competition, profits will fall, small companies disappear, huge monopolies take over, taxes will be evaded and there will be transfer pricing. But populist politicians blame 'the other', the blacks, the Jews, the foreigner. And this appeals to people who are marginalised by the system, who are scared and fall for nationalist rhetoric.”

And he was even more pessimistic about the climate crisis. "We're staring at a disaster. The so-called solutions offered by Trudeau, Macron, Trump are not solutions at all.” In August 2019, just two weeks before he died, David published a commentary in the 
Lancet criticizing the shift from primary health care to universal health coverage. He wrote that this 'signals the risk of further medicalisation and commercialisation of health care under the UHC model.' ... 'Instead, Astana (the follow-up Declaration to Alma Ata) calls for "partnership” with the private sector, notwithstanding the mounting evidence of the commercial determinants of ill-health such as alcohol, tobacco, ultra-processed foods, and industrial and automobile pollution.... Low and middle-income countries are often unable or unwilling to regulate the private sector. The power of transnational corporations...transcends national boundaries and requires strong and decisive global action both by global civil society and international institutions. In 2018, for example, of the 100 entities with the highest annual revenues, 69 were corporations and 31 were governments."

David had immense influence on a whole generation of health professionals and campaigners. The greatest tribute we can pay him is to take up the 'causes of the causes' that he espoused and continue his struggle for health.

\section{Bibliography}

David Sanders. The Struggle for Health. The Medicine and Politics of Underdevelopment. Macmillan 1985. https://www.amazon.co.uk/Struggle-HealthMedicine-Politics-Underdevelopment/dp/0333375297

David Werner and David Sanders, with Jason Weston, Steve Babb and Bill Rodriguez. Questioning the Solution: The Politics of Primary Health Care and Child Survival with an in-Depth Critique of Oral Rehydration Therapy. 1997. Palo Alto, CA: Health Wrights.

Fatal Indifference: The G8, Africa and Global Health Paperback - 30 Sep 2003 Ronald Labonte (Editor), Ted Schrecker (Editor), David Sanders (Editor), Wilma Meeus (Editor) UCT Press. https://www.amazon.co.uk/Fatal-Indifference-Africa-GlobalHealth/dp/1919713840

In July 2018 David Sanders gave an extended interview on the podcast: http://www.anthonycostello.net/podcast/how-to-be-a-social-activist-for-health-aninterview-with-david-sanders/

David Sanders Sulakshana Nandi Ronald Labonté Carina Vance Wim Van Damme. From primary health care to universal health coverage - one step forward and two steps back. The Lancet August 24 2019. 